\title{
Editorial on this Focus Issue on Key Corrosion Topics
}

\section{Yves Wouters $^{1}$ - Bruce Pint ${ }^{2}$ - Daniel Monceau ${ }^{3}$ - Michel Vilasi ${ }^{4}$. Sébastien Chevalier ${ }^{5}$. Laurence Latu-Romain ${ }^{1} \cdot$ Clara Desgranges $^{6}$}

Published online: 26 July 2021

(c) The Author(s), under exclusive licence to Springer Science+Business Media, LLC, part of Springer Nature 2021

This focus issue explores a number of current topics in high-temperature oxidation, some that have been of interest for many decades and others with more recent origins. For example, Griffith and Pfeil's 1937 patent for rare earth additions such as $\mathrm{Y}$ and $\mathrm{Sc}$ to $\mathrm{Ni}-\mathrm{Cr}$ alloys is nearly 85 years old, and we still continue to study minor alloy additions (including $\mathrm{Hf}$ ) and aspects of $\mathrm{Ni}-\mathrm{Cr}$ alloy performance because of their technological importance to many industrial applications. The alloys in this issue range from low-alloy steels to superalloys and shape-memory alloys. The experiments are often complex, as environments such as steam, $\mathrm{CO}_{2}$ and molten salts are being considered for current and future applications. In some cases,

Yves Wouters

yves.wouters@univ-grenoble-alpes.fr

Bruce Pint

pintba@ornl.gov

Daniel Monceau

daniel.monceau@toulouse-inp.fr

Michel Vilasi

Michel.Vilasi@univ-lorraine.fr

Sébastien Chevalier

sebastien.chevalier@u-bourgogne.fr

Laurence Latu-Romain

Laurence.latu-romain@univ-grenoble-alpes.fr

Clara Desgranges

clara.desgranges@safrangroup.com

1 SIMaP, Université Grenoble Alpes, Grenoble, France

2 Oak Ridge National Laboratory, Materials Science and Technology Division, Oak Ridge, TN, USA

3 CNRS, CIRIMAT/Université de Toulouse, Toulouse, France

4 IJL/Université de Lorraine, Nancy, France

5 ICB/Université de Bourgogne, Dijon, France

6 Safran-Tech, Châteaufort, France 
coatings may be required for use in the extreme environments of turbines or solid oxide fuel cells. Modeling is incorporated to gain more insight with examples studying coating failure mechanisms and multilayer reaction products. Microstructure is a critical aspect including its impact on oxidation resistance but also the impact of oxidation on mechanical properties. Finally, test parameters are explored including the effect of thermal cycling on hot corrosion and the effect of gas pressure and the reaction tube material on oxidation behavior.

The following papers stem from presentations that were given at the 10th International conference on High Temperature Corrosion and Protection of Materials (HTCPM2021), which was delayed because of COVID-19 and held virtually on March 29-April 2, 2021.

Publisher's Note Springer Nature remains neutral with regard to jurisdictional claims in published maps and institutional affiliations. 